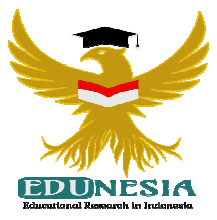

\title{
PENGEMBANGAN MEDIA PEMBELAJARAN POP - UP BOOK UNTUK MENINGKATKAN MOTIVASI BELAJAR SISWA KELAS IV SD
}

\author{
Melin Sri Ulfa'; Cut Eva Nasryah ${ }^{2}$ \\ 1,2Pendidikan Guru Sekolah Dasar, STKIP Bina Bangsa Meulaboh, Indonesia \\ ${ }^{2}$ Corresponding Email: cut.evanasryah11@gmail.com, Phone Number :0812 xxxx xxxx
}

Article History:
Received: Des 19, 2019
Revised: Jan 10, 2020
Accepted: Jan 28, 2020
Published: Jan 30, 2020

Keywords:

Borg and Gall's Model

Leaning Media

Motivation

Pop-up Book

\section{Kata Kunci:}

Media Pembelajaran

Model Borg and Gall

Motivasi

Pop-up Book

\section{How to cite:}

Ulfa, M.S., \& Rahman, A.A. (2020). Pengembangan Media Pembelajaran Pop - Up Book Untuk Meningkatkan Motivasi Belajar Siswa Kelas IV SD. Edunesia : Jurnal Ilmiah Pendidikan, 1 (1): 10-16

\begin{abstract}
This study aims to, 1) describe the development of pop-up book learning media to increase student motivation, 2) to describe whether the development of pop-up book learning media is effective in increasing student learning motivation on theme 6 of sub-theme 1 of animal and plant diversity class IV in Ujong Tanjong Public Elementary School. The type of research used is Research and Development with the procedural research and development of Borg and Gall. The instrument in this study was the validation sheet of media experts and material experts, as well as the student response questionnaire sheet and teacher response questionnaire, all learning motivation of each student was seen to be more improved during the learning process using pop-up media, it could be seen from the student response questionnaire. The pop-up book learning media was created using PicsArt Photo Studio and Microsoft Word 2010. Based on the analysis of media expert assessment data of 3.33 with the category of "valid", material expert assessment of 3.60 with the category of "valid", assessment of the response of educators amounted to 3.60 with the category "valid", the assessment of students' responses in the first try was $95.8 \%$ with the "very good" category and in the second trial test was $98.3 \%$ with the "very good" criteria. So that the pop-up book material diversity of animals and plants meet the criteria for use as a learning medium.
\end{abstract}

\begin{abstract}
Abstrak: Penelitian ini bertujuan, 1) mendeskripsikan pengembangan media pembelajaran pop - up book untuk meningkatkan motivasi belajar siswa, 2) untuk mendeskripsikan apakah pengembangan media pembelajaran pop - up book efektif dalam meningkatkan motivasi belajar siswa pada tema 6 subtema 1 keanekaragaman hewan dan tumbuhan kelas IV di SD Negeri Ujong Tanjong. Jenis penelitian yang digunakan adalah Research and Development dengan prosedural penelitian dan pengembangan dari Borg and Gall. Instrument dalam penelitian ini adalah lembar validasi ahli media dan ahli materi, serta lembar angket respon siswa dan angket respon guru, semua motivasi belajar dari setiap siswa terlihat lebih meningkat selama proses pembelajaran menggunakan media pop - up berlangsung, hal itu dapat dilihat dari angket respon siswa. Media pembelajaran pop - up book ini dibuat menggunakan PicsArt Photo Studio dan Microsoft Word 2010. Berdasarkan analisis data penilaian ahli media sebesar 3,33 dengan kategori "valid", penilaian ahli materi sebesar 3,60 dengan kategori "valid", penilaian respon tenaga pendidik sebesar 3,60 dengan kategori "valid", penilaian respon peserta didik pada uji coba I sebesar 95,8\% dengan kategori "sangat baik" dan pada uji voba II sebesar $98,3 \%$ dengan kriteria "sangat baik". Sehingga pop - up book materi keanekaragaman hewan dan tumbuhan memenuhi kriteria untuk digunakan sebagai media pembelajaran.
\end{abstract}




\section{A. Pendahuluan}

Dalam kehidupan manusia tidak dapat terlepas dari pendidikan dan pembelajaran. Namun dalam kegiatan pembelajaran setiap siswa memiliki kemampuan yang berbeda beda dalam memahami konep pembelajaran . Hal ini dapat menjadikan mereka memiliki perbedaan pendapat dalam menyelesaikan suatu permasalahan. Semakin dikuasainya suatu konsep dalam pembelajaran diharapkan pemecahan masalah menjadi semakin mudah, dan hasil belajar menjadi lebih baik. Dalam proses pembelajaran di kelas, seorang guru sering kali menjumpai siswa yang mengalami kesulitan belajar (Anzar dan Mardhatillah, 2017).

Untuk memudahkan siswa dalam memahami konsep materi dalam proses pembelajaran maka dibutuhkan media. Media sangat penting dalam melakukan proses pembelajaran siswa karena dengan media motivasi siswa dapat lebih meningkat, selain itu siswa juga dapat mengamati secara langsung tanpa membayang - bayangkan serta informasi selama pembelajaran dapat terus diulang sesuai dengan kebutuhan. Media juga bermanfaat bagi guru dalam menyampaikan materi pembelajaran. Dengan media yang tepat proses pembelajaran dapat berlangsung secara efektif dan tujuan pembelajaran lebih mudah tercapai.

Agar proses belajar sesuai dengan yang guru inginkan, maka siswa memerlukan motivasi. Nurjannah \& Khairani (2019) mengungkapakn bahwa "Jika motivasi rendah, maka semua kemampuan kognitifnya juga akan berkurang. Diperlukan kata - kata motivasi sebelum memulai pembelajaran di dalam kelas agar motivasi dalam diri peserta didik dapat muncul". Peran motivasi sangat diperlukan dalam proses pembelajaran, hal itu dikarenakan semakin besar motivasi yang ada pada diri siswa maka semakin bagus pula hasil belajar yang akan didapatkan. Motivasi dipengaruhi oleh beberapa faktor baik itu faktor internal maupun faktor eksternal. Faktor internal merupakan faktor yang timbul dari dalam diri siswa, seperti kondisi kesehatan, minat belajar dan lain sebagainya. Sedangkan faktor eksternal merupakan faktor yang timbul dari luar, seperti guru, lingkungan (keluarga, sekolah, masyarakat), ketersediaan sarana dan prasarana, metode dan strategi mengajar.

Sesuai pengamatan yang peneliti di SD Negeri Ujong Tanjong, selama proses pembelajaran berlangsung tidak sedikit siswa yang tidak fokus selama proses belajar mengajar, kebanyakan siswa jarang mengerjakan tugas yang diberikan oleh guru serta mudah merasa putus asa, siswa sering kali cepat puas dengan hasil yang mereka dapatkan dan tidak memiliki semangat bersaing dengan teman - temannya yang lain. Selain itu siswa juga tidak memiliki semangat belajar serta tidak senang mencari dan memecahkan soal - soal yang diberikan kepada mereka. Dengan memperhatikan perilaku para siswa, peneliti menduga bahwa rendahnya motivasi belajar dipengaruhi oleh penggunaan media pembelajaran. Peran media pembelajaran sangatlah penting dalam membantu guru dalam menyampaikan materi yang diajarkan. Tentunya guru dalam menyampaikan materi pelaran harus dapat memotivasi siswa.

Selama ini kebanyakan guru menggunakan buku teks sebagai media pembelajarannya karena dianggap lebih praktis dan mudah di bawa. Padahal buku teks tematik yang digunakan oleh guru masih terdapat banyak kekurangan, dikarenakan materi yang ada terkadang tidak memadai sehingga guru harus mencari penguatan materi lainnya. Menurut Rohani (dalam Nurjannah, 2013) “peran media pembelajaran adalah membangkitkan minat belajar yang baru dan membangkitkan motivasi kegiatan belajar siswa". Tentu dengan adanya perkembangan ilmu pengetahuan dan tekhnologi, kita perlu 
menambahkan media yang dapat membantu usaha guru dalam membangkitkan motivasi belajar siswa. Selama proses pembelajaran berlangsung media yang digunakan juga harus efektif.

Sinurat dan Syahputra (2015) dalam penelitiannya berkesimpulan "jika dalam proses pembelajaran guru menggunakan media pembelajaran yang memiliki keefektifan yang tinggi maka akan berdampak baik pada prestasi belajar siswa". Dari pendapat tersebut dapat kita simpulkan bahwa keefektifan suatu media pembelajaran dapat dilihat dari hasil belajar yang diperoleh siswa. Namun selain hasil belajar, keefektifan media pembelajaran juga dapat dilihat dari respon yang diberikan oleh siswa selama proses pembelajaran berlangsung. Dengan menggunakan media pembelajaran yang tepat maka akan membuat siswa merasa antusias dan menjadi lebih aktif selama proses pembelajaran berlangsung.

Untuk mengatasi permasalahan tersebut, perlu adanya media pembelajaran yang mendukung selama proses belajar mengajar serta dapat meningkatkan motivasi siswa. Sehingga perlu adanya media berupa buku interaktif dikarenakan guru lebih bergantung dengan buku teks layaknya Pop-Up Book. Pop-Up Book adalah jenis buku atau kartu yang didalamnya terdapat lipatan gambar yang dipotong dan muncul dalam bentuk lapisan tiga dimensi ketika halaman tersebut di buka (Febrianto, dkk, 2014). Menurut Widowati, dkk (2015:22) Pop-Up Book dapat memberikan visualisasi cerita yang lebih menarik mulai dari gambar yang terlihat memiliki tampilan tiga dimensi dan kinetik, gambar yang dapat bergerak ketika halamannya dibuka atau bagiannya digeser dapat bergerak sehingga dapat membentuk seperti benda aslinya.

Dzuanda (2011) "Pop -Up Book adalah sebuah buku yang memiliki bagian yang dapat bergerak atau memiliki unsur 2 dimensi dan 3 dimensi serta memberikan visualisasi cerita yag menarik, mulai dari tampilan gambar yang dapat bergerak ketika halamannya dibuka". Dengan penggunaan media Pop - Up Book ini sangat sesuai dengan potensi anak, selain itu media ini juga sangat praktis, menarik, dan simple. Dengan adanya media ini siswa dapat menjadi lebih bersemangat dalam menjalani proses pembelajaran dikarenakan adanya gambar yang disajikan.

Dalam proses pembelajaran di SD Negeri Ujong Tanjong ditemui bahwa guru sangat jarang menggunakan media yang tepat dalam memberikan pembelajaran. Secara teoritik siswa Sekolah Dasar berfikir secara konkret namun guru seringkali memberikan pembelajaran dengan berfikir abstrak, dengan menggunakan kata - kata yang menyebabkan siswa kesulitan dalam membayangkan hal - hal yang diajarkan oleh guru. Seharusnya pembelajaran dilakukan dengan menggunakan media pembelajaran yang sesuai dengan tingkat usia siswa.

Pemilihan media pembelajaran dengan menggunakan media Pop - Up Book dirasa sangat tepat karena sangat mudah di bawa ke dalam kelas, selain itu gambar yang disajikan berbentuk konkrit karena berbentuk tiga dimensi sehingga lebih menarik untuk dibaca.

\section{B. Metode}

Jenis penelitian yang digunakan pada penelitian ini ialah penelitian dan pengembangan (Research and Development). Penelitian dan pengembangan adalah suatu proses atau langkah - langkah untuk mengembangkan suatu produk baru atau menyempurnakan produk yang telah ada, yang dapat dipertanggung jawabkan (Sukmadinata, 2012). Sejalan dengan pendapat Sugiyono (2011) yang mengatakan bahwa 
metode penelitian dan pengembangan adalah metode penelitian yang digunakan untuk menghasilkan produk tertentu dan menguji kefektifan produk tersebut.

Dalam penelitian ini peneliti menggunakan pendekatan kualitatif. Menurut Arikunto (2010), "penelitian kualitatif merupakan penelitian yang dituntut untuk tidak menggunakan angka dalam mengumpulakn data berupa informasi berbentuk kalimat yang memberikan gambaran tentang ekspresi siswa tentang tingkat pemahaman terhadap suatu mata pelajaran (kognitif), pandangan atau sikap siswa terhadap metode belajar yang baru (afektif) aktivitas siswa mengikuti pelajaran, perhatian, antusias dalam belajar, kepercayaan diri, motivasi belajar dan sejenisnya, yang dapat dianalisis secara kualitatif".

Penulis menggunakan penelitian yang diadaptasi dari model penelitian dan pengembangan (R\&D) yang mengacu pada model Borg and Gall yang telah dimodifikasi oleh sugiyono. Pada model ini terdapat 10 langkah dalam menghasilkan suatu produk. Adapun langkah - langkah tersebut antara lain (1) potensi dan masalah, (2) pengumpulan data, (3) desain produk, (4) validasi desain, (5) revisi desaij, (6) uji coba produk, (7) revisi produk, (8) uji coba pemakaian, (9) revisi produk, (10) produksi masal. Berikut tahap - tahap penelitian yang peneliti laksanakan:

1. Potensi dan Masalah

Sebelum melakukan pegembangan media Pop - up book, peneliti melakukan observasi guna mencari potensi dan masalah di SD Negeri Ujong Tanjong. Potensi dari sekolah tersebut adalah tingginya minat belajar para peserta didik. Sedangkan masalah yang ada adalah minimnya media pembelajaran yang dapat menarik dan memotivasi peserta didik untuk belajar. Dengan adanya potensi dan masalah tersebut, maka peneliti mengembangkan media Pop - up book untuk meningkatkan motivasi siswa.

\section{Pengumpulan data}

Pada tahap ini peneliti mengumpulkan data dan informasi dengan melakukan beberapa metode pengumpulan data, antara lain:

a. Wawancara

Menurut Esterberg yang dikuti oleh Sugiyono, Wawancara adalah pertemuan dua orang untuk bertukar informasi dan ide melalui tanya jawab, sehingga dapat dikonstruksikan makna dalam suatu topik tertentu. Wawancara dilakukan dengan pendidik yang mengajar dikelas IV, kegiatan tersebut dilakukan untuk mengetahui kebutuhan media pembelajaran serta karakteristik dalam pembelajaran terutama pada pembelajaran tema 6 subtema 1 kenaekaragaman hewan dan tumbuhan dikelas IV SD Negeri Ujong Tanjong.

b. Observasi

Observasi berasal dari bahasa latin yaitu melihat dan memperhatikan. Banister juga mengatakan bahwa observasi diarahkan pada kegiatan memperhatikan secara akurat, mencatata fenomena yang muncul dan mempertimbangkan hubungan antar aspek dan fenomena tersebut. Hal ini dilakukan agar peneliti mengetahui secara langsung kondisi yang terjadi di sekolah tersebut, dan mengetahui secara langsung bagaimana karakteristik siswa di sekolah khususnya siswa kelas IV.

\section{Desain Produk}

Setelah melakukan pengumpulan data dan informasi, selanjutnya peneliti mulai membuat media pembelajaran Pop - up book. Pada tahap ini peneliti mempelajari cara 
pembuatan dan penggunaan Pop - up book, kemudian menyiapkan materi yang akan dikembangkan pada media pembelajaran.

4. Validasi Desain

Validasi desain merupakan suatu langkah yang dilakukan untuk menguji kelayakan suatu produk sebelum di melakukan ujicoba lapangan agar media menjadi lebih efektif. Validasi dilakukan oleh ahli materi dan ahli media.

\section{Revisi Desain}

Setelah desain produk divalidasi, maka peneliti melakukan revisi pada desain produk berdasarkan masukan - masukan validator ahli.

\section{Uji Coba Produk}

Setelah melakukan revisi dari desain produk, maka langkah selanjutnya peneliti dapat melakukan uji coba produk. Uji coba produk dilakukan untuk mengetahui efektivitas dari produk yang dikembangkan.

\section{Revisi Produk}

Setelah melakukan uji coba, maka peneliti akan melakukan revisi pada media pembelajaran Pop - up book yang telah dibuat berdasarkan hal - hal yang belum dicapai pada uji coba pertama.

\section{Uji Coba Pemakaian}

Setelah melakukan revisi pada produk yang dikembangkan selanjutnya peneliti kembali melakukan uji coba pemakain menggunakan media Pembelajaran Pop - up book tersebut.

\section{Revisi Produk}

Setelah uji coba kembali dilakukan maka peneliti akan kembalai merevisi media pembelajaran Pop - up book sesuai dengan masukan yang diberi oleh pihak terkait untuk menyempurnakan hasil akhir dari media pembelajaran Pop - up book yang dikembangkan.

\section{Produksi Massal}

Setelah media Pop - up book telah direvisi maka peneliti akan memproduksi media pembelajaran Pop - up book, namun dikarenakan biaya ayng tidak banyak maka media pebelajaran Pop - up book tersebut hanya diproduksi sesuai kebutuhan penelitian saja. Teknik yang digunakan untuk mengumpulkan data dalam penelitian ini yaitu :

a) Observasi adalah alat bantu yang digunakan dalam pengumpulan data-data melalui pengamatan dan pencatatan yang sistematis terhadap berbagai hal tentang keadaan objek penelitian. Menurut Narbuko (2013) Observasi yaitu mengamati dan melihat secara langsung fenomena yang diselidiki dalam penelitian.Metode ini digunakan agar peneliti dapat melihat dan mengamati sendiri kemudian mencatat peristiwa yang terjadi selama proses pembelajaran berlangsung.

b) Angket respon peserta didik digunakan untuk mengukur aspek keefektifan yang bertujuan untuk mendapatkan data mengenai tanggapan peserta didik tentang proses pembelajaran yang dialami menggunakan media pembelajaran Pop - up book. Angket 
ini berisi pernyataan menarik atau tidaknya media pembelajaran Pop - up book dengan mengisi dikolom pernyataan "Ya" atau "Tidak".

Instrument penelitian ddalam penelitian ini adalah lembar validasi ahli, angket respon peserta didik dan angket respon guru. Instrument penelitian diberikan kepada validator di buat dalam bentuk skala likert. Skor rata - rata penilaian diperoleh dengan rumus

$$
\begin{aligned}
& \text { Skor rata }- \text { rata }=\frac{\text { skor total }}{\text { banyak butlr }} \\
& \text { Skor rata }- \text { rata keseluruhan }=\frac{\text { jwnlch skor rata }- \text { rata }}{\text { bangak aspel }}
\end{aligned}
$$

Selanjutnya nilai Va atau nilai kevalidan suatu media pembelajaran Pop - up book dapat dilihat pada tabel 1 berikut

Tabel 1. Kriteria Tingkat Kevalidan

\begin{tabular}{cc}
\hline Interval skor & Kriteria \\
\hline $1 \leq \mathrm{Va}<2$ & Tidak Valid \\
\hline $2 \leq \mathrm{Va}<3$ & Kurang Valid \\
\hline $3 \leq \mathrm{Va}<4$ & Valid \\
\hline $\mathrm{Va}=4$ & Sangat Valid \\
\hline
\end{tabular}

Keterangan :

Va : Valid

\section{Hasil dan Pembahasan}

Hasil validasi oleh ahli media diperoleh skor rata - rata sebesar 3,33 dengan kriteria "Valid". Saran yang diberikan oleh ahli media adalah tulisan yang harus dirapikan dan dan perbaiki setiap materi yang tertutup oleh gambar. Hasil validasi oleh ahli materi mendapatkan nilai rata - rata sebsar 3,60 dengan kriteri "Valid". Saran yang diberikan oleh ahli materi adalah agar tidak terlalu banyak meletakkan materi kedalam bentuk surat agar siswa tidak terlalu merasa repot saat belajar. Kemudian penilaian dari guru kelas IV mendapatkan nilai rata - rata sebsar 3,53 dengan kriteria "Valid". Saran yang diberikan oleh guru kelas adalah memberikan nomor pada setiap halaman buku.

Terlihat juga pada hasil uji coba yang dilakukan terhadap siswa pada uji coba I didapatkan skor keseluruhan sebesar 95,8\% dengan kriteria "Sangat Baik". Pada uji coba I dari 15 pernyataan yang ada pada angket respon siswa didapatkan hasil bahwa 9 siswa $(37,5 \%)$ memilih pilihan "Iya" sedangkan 15 siswa (62,5\%) memilih pilihan "Tidak". Dari hasil di atas dapat dikatakan media pembelajaran Pop - Up Book belum efektif karena persentase siswa yang memilih jawaban "Iya" tidak mencapai $61 \%$. Adapun pada uji coba I siswa memberikan komentar untuk memperbaiki gambar yang terlalu kecil. Namun pada uji coba II didapatkan skor keseluruhan sebesar 8,3\% dengan kriteria "Sangat Baik". Pada uji coba II dari 15 pernyataan yang ada pada angket respon siswa didapatkan hasil bahwa 18 siswa (75\%) memilih pilihan "Iya" sedanhkan 6 siswa $(25 \%)$ memllih pilihan "Tidak". Dan pada uji coba II siswa juga memberikan komentar untuk memberikan setiap keterangan pada beberapa gambar yang lupa diberikan keterangan. Dari hasil di atas maka dapat disimpulkan bahwa media pembelajaran Pop - Up Book telah efektif dan mendapatkan respon yang sangat baik dan positif dari peserta didik 


\section{Kesimpulan}

Respon validator terhadap media pembelajaran Pop - Up Book berdasarkan penilaian ahli media memperoleh skor rata - rata sebesar 3,33 dengan kriteria "valid", penilaian ahli materi memperoleh skor rata - rata sebesar 3,60 dengan kriteria "valid", serta penilaian dari guru kelas IV memperoleh skor rata - rata sebesar 3,53 dengan kriteria "valid".

Respon peserta didik terhadap media pembelajaran Pop - Up Book yang dilakukan dengan uji coba pada siswa kelas IV di SD Negeri Ujong Tanjong memperoleh persentase rata - rata sebesar 98,3\% dengan kategori "Sangat Baik". Hal ini menunjukkan bahwa media pembelajaran Pop - Up Book mendapatkan respon sangat baik dan positif dari peserta didik dan tenaga pendidik. Sehingga dengan demikian media pembelajaran Pop Up Book telah efektif dan dapat meningkatkan motivasi belajar siswa.

\section{Daftar Pustaka}

Anzar, S.F., \& Mardhatillah. (2017). “Analisis Kesulitan Belajar Siswa Pada Pembelajaran Bahasa Indonesia Di Kelas V SD Negeri 20 Meulaboh Kabupaten Aceh Barat Tahun Ajaran 2015/2016". Jurnal Ilmiah Pendidikan Guru Sekolah Dasar. Vol. 4 No.1.

Arikunto, S. (2010). Prosedur Penelitian Suatu Pendekatan Praktik. Jakarta. Rineka Cipta.

Dzuanda, B. (2011). Perancangan Buku Cerita Anak Pop - Up Tokoh - Tokoh Wayang Seri "Gatotkaca" (Tugas Akhir). Surabaya: Institut Teknologi Sepuluh November Surabaya.

Narbuko, C., \& Ahmadi, A. (2013) Metodologi Penelitian. Jakarta: Bumi Aksara.

Nurjannah, E. (2013). Pengaruh Media Film Terhadap Motivasi Belajar Siswa Dalam Pembelajaran Pendidikan Kewarganegaraan (PKN). Tesis. Pascasarjana Universitas Pendidkan Indonesia.

Nurjannah., \& Khairani. (2019). “Penerapan Model pembelajaran Kooperatif Tipe Jigsaw Untuk Meningkatkan Motivasi dan Hasil Belajar Siswa Pada Pembelejaran Bahasa Indonesia Kelas V SD Negeri Pasi Pinang Kecamatan Meureubo. Jurnal Genta Ilmiah. Vol. X No. 1.

Sinurat, M., \& Syahputra, E. (2015) Pengembangan Media Pembelejaran Matematika Berbantuan Program Flash Untuk Meningkatkan Kemampuan Matematika Siswa SMP. Medan, Vol. 12 No. 2.

Sukmadinata. (2012). Metode Penelitian Pendidikan. Bandung: PT. Remaja Rosdakarya. Sugiyono. (2011). Metode Penelitian Kualitatif, Kuantitatif dan RED. Bandung: Alfabeta 